\title{
Penerapan Metode Clustering K-Means Untuk Membantu Menentukan Tingkatan Status Daerah Dampak Covid-19
}

\author{
Eki Juliana ${ }^{1}$, Vivi Nur Aleyda ${ }^{2}$, Yuliana ${ }^{3}$ \\ Sistem Informasi, UNDA University \\ ${ }^{1}$ Ekijuliana6@Gmail.com \\ ${ }^{3}$ Vnurlyda@gmail. com \\ ${ }^{3}$ yuliana08016@gmail.com
}

\begin{abstract}
Abstrak - Penyakit menular yang dapat menyerang daerah pernafasan telah dideteksi masuk di Indonesia sekitar awal tahun 2020 yaitu Corona Virus Disease-2019 atau Covid-19. Penularan virus ini cukup ringan dengan cairan yang dikeluarkan seseorang dari hidung, bersin, dan batuk dari pasien yang terjangkit, maka dari itu penularannya sangat cepat. Perkembangan klaster covid-19 ini dapat diakibatkan dari faktor manusianya yang tidak mematuhi peraturan protokol kesehatan. Peristiwa ini dapat diketahui dari jumlah kasus Covid-19 tertinggi antar per provinsinya yaitu Jakarta dengan kasus positif 9.128 jiwa perhari dengan kesembuhan 11.857 jiwa perhari, sedangkan penularan Covid-19 dengan kasus yang terendah penyebarannya adalah Maluku terdapat 69 jiwa kasus positif perhari dan kesembuhannya 23 jiwa perhari. Penelitian ini menerapkan algoritma k-means clustering dengan batuan tool weka agar dapat melakukan pengklasifikasian pengelolaan kasus Covid-19 untuk menetukan pengelompokan status zona pada setiap provinsinya dengan menggunakan 3 cluster yaitu rendah, Sedang dan Tinggi. Sehingga diperoleh hasil data 4 provinsi zona Merah, 11 Provinsi zona Kuning, dan 19 provinsi zona hijau.
\end{abstract}

Kata Kunci: Algoritma K-means, Clustering, Covid-19, Status Zona, tool weka

\section{PENDAHULUAN}

Pada awal tahun 2020 terdapat sebuah virus yang membuat semua orang didunia khususnya di Wuhan, China menjadi heboh dan ketakutan Virus tersebut yaitu CoronaVirus Disease-2019 atau Covid-19. Virus tersebut baru diidentifikasi sebagai sebagai SARSCoV-2, virus ini pertama kali terdeteksi didaerah wuhan, China pada desember 2019 lalu kemudian mulai menyebar keseluruh negara-negara lain. Penyebaran virus ini sangat cepat sehingga masyarakat indonesia menimbulkan ketakutan dan keresahan pada virus tersebut karena penyebarannya dapat melalui cairan yang dikeluarkan seseorang dari hidung, bersin, dan batuk dari pasien yang terjangkit. Kemudian pemerintah langsung melakukan pemberlakuan kebijakan-kebijakan yaitu salah satunya Pemberlakuan Pembatasan Kegiatan Masyarakat (PPKM) yang saat ini sedang di terapkan.

Semenjak Indonesia terdeteksi Covid-19 pada awal tahun 2020, kasusnya semakin meningkat dengan cepat. Provinsi yang pertama kali terdampak adalah jakarta dan yang paling tinggi tingkat kasusnya diantara provinsi lainnya yang ada di Indonesia sampai saat ini pemantauan data pada tanggal 18 juli 2021 dengan kasus positif 9.128 jiwa perhari dengan kesembuhan 11.857 jiwa perhari, sedangkan penularan Covid-19 dengan kasus yang terendah penyebarannya adalah Maluku terdapat 69 jiwa kasus positif perhari dan kesembuhannya 23 jiwa perhari. Pemantauan data pada tanggal 18 juli 2021 di seluruh provinsi Indonesia dengan kasus Positif mencapai 44.721 jiwa, Sembuh mencapai 29.264 jiwa dan Kematian mencapai 1.093 jiwa atau sebanding 78,6 \%. Sehingga masyarakat harus membentuk imun tubuh yang baik agar kita dianjurkan untuk mengonsumsi vitamin c, buah-buahan dan sayuran yang cukup serta menjaga pola tidur yang baik dan berjemur dipagi hari. Karena Sampai saat ini banyak sekali orang yang terjangkit virus ini tetapi tidak memiliki gejala seperti batuk ataupun panas yang tinggi, dan sekarang pun belum ditemukan obat untuk virus ini, walaupun dunia sudah membuat sebuah vaksin untuk virus ini tetapi belum menutup kemungkinan seseorang yang sudah divaksin tersebut tidak dapat lagi terjangkit virus ini.

Dalam penelitian ini bertujuan untuk melakukan clustering pada data penularan Covid-19 di provinsi seluruh Indonesia Sehingga dapat membantu untuk membentuk cluster zona penyebaran covid-19. Clustering ini adalah metode data mining yang dapat digunakan dalam melakukan pengategorian data yang serupa atau sama sehingga menjadi cluster. Proses penggunaan algoritma clustering yaitu dengan mencari data pada seluruh set/bagian dan dijadikan sebuah kelompok atau bagian kelompok. Adapun harapan dari penelitian ini agar dapat membatu pemerintah dalam mengelompokan zona penyebaran covid-19 dan memberikan keterangan status zona dari angka penyebaran covid tertinggi, sedang dan rendah.

\section{METODE PENELITIAN}

A. Tahap Pengumpulan Data

Data yang digunakan dalam penelitian ini di peroleh dari kasus penyebaran covid-19 pada tanggal 18 Juli 2021 dari 34 provinsi yang ada di indonesia yang di ambil langsung dari situs web resmi Data Riset dan Teknologi Covid-19 Indonesia (ristekbrin.go.id).

B. Pembagian Zona di Indonesia pada pandemi covid-19

Menurut Gugus Tugas Percepatan Penanganan Covid-19, kriteria zonasi wilayah berdasarkan warna tersebut merupakan indikator kategori risiko Covid-19 yang dilihat dari tingkat penularannya ataupun penyebarannya

Berikut ini Beberapa pembagian zona di Indonesia

1. Zona Hijau ( Tidak Terdampak atau sudah tidak terinfeksi virus covid 19

2. Zona Kuning ( Resiko penyebaran covid rendah)

3. Zona Orange ( Resiko penyebaran covid sedang )

4. Zona Merah ( Resiko penyebaran covid Tinggi)

C. Metode Clustering

Clustering adalah memisahkan data ke dalam kelompokkelompok yang memiliki obyek dengan karakteristik yang serupa. Clustering ini merupakan awalan dari sebuah data mining.[3]

D. Algoritma K-Means

Salah satu algoritma Clustering adalah K-Means yang digunakan untuk mengelompokkan data menjadi beberapa kelompok dengan beberapa Cluster.[1] Data - data dipilih menjadi beberapa kelompok dengan kriteria yang telah ditentukan lalu dikumpulkan menjadi satu dalam sebuah Cluster.Dimana setiap Cluster memiliki titik pusat yang disebut Centroid. Berikut adalah tahapan-tahapan untuk melakukan optimasi mengunakan algoritma K-Means[1]

1. Pilihlah jumlah Cluster $(\mathrm{k})$ yang diinginkan pada dataset

2. Tentukan titik pusat (Centroid) secara acak/random pada tahap 
awal

3. Hitunglah jarak terdekat setiap data dengan Centroid. Untuk menghitung jarak terdekat dengan Centroid adalah Euclidean distance

4. Hitung kembali pusat Cluster dengan keanggotaan Cluster yang sekarang.Pusat Cluster adalah rata - rata dari semua data dalam sebuah Cluster.

5. Kelompokan hasil cluster dan berikan tanda warna

E. Waikato Environment for Knowledge Analysis (WEKA)

WEKA adalah sebuah paket tools machine learning praktis.

WEKA merupakan singkatan dari Waikato Environment for Knowledge Analysis, yang dibuat di Universitas Waikato, New Zealand untuk penelitian, pendidikan dan berbagai aplikasi. WEKA mampu menyelesaikan masalah-masalah data mining di dunia nyata, khususnya klasifikasi yang mendasari pendekatanpendekatan machine learning. Perangkat lunak ini ditulis dalam hirarki class Java dengan metode berorientasi objek dan dapat berjalan hampir di semua platform.[4]

\section{HASIL DAN PEMBAHASAN}

A. Data Pengujian

Pengunaan data yang di gunakan dalam penelitian ini berupa dataset kasus penularan covid 19 yang terdiri dari 7 atribut yaitu nama provinsi, kasus positif, kasus positif hari ini, kasus sembuh, kasus sembuh hari ini , kasus meninggal, kasus meninggal hari ini dan 34 data Provinsi Indonesia.

Tabel 1. Dataset Kasus Pasisen Covid 19 Disetiap Provinsi Pada 18 Juli 2021

\begin{tabular}{|c|c|c|c|c|c|c|}
\hline Prexinsi Asal & Kasus & $\begin{array}{c}\text { Kasus Hari } \\
\text { ini }\end{array}$ & Sembuh & $\begin{array}{c}\text { Sembuh } \\
\text { Hari Ini }\end{array}$ & Kematian & $\begin{array}{c}\text { Kematian } \\
\text { Hari ini }\end{array}$ \\
\hline Aceh & 20949 & 63 & 16193 & 86 & 923 & 8 \\
\hline Bali & 61179 & 944 & 52293 & 465 & 1769 & 20 \\
\hline Banten & 87718 & 3139 & 55381 & 310 & 1554 & 9 \\
\hline Bangka Belitung & 26777 & 309 & 22371 & 271 & 455 & 10 \\
\hline Bengkulu & 14003 & 468 & 10569 & 232 & 256 & 1 \\
\hline Yogyakarta & 92084 & 2119 & 62428 & 780 & 2382 & 48 \\
\hline Jakarta & 746312 & 9128 & 627462 & 11857 & 10167 & 158 \\
\hline Jambi & 16441 & 442 & 12809 & 133 & 321 & 6 \\
\hline Jawaa Barat & 516591 & 7777 & 390203 & 3895 & 7340 & 91 \\
\hline Jawa Tengah & 321763 & 4699 & 245593 & 3420 & 14397 & 179 \\
\hline Jawas Timur & 239168 & 5726 & 178766 & 3053 & 15836 & 328 \\
\hline Kalimantan Barat & 21149 & 358 & 15987 & 249 & 501 & 12 \\
\hline Kalimantan Timus & 96564 & 1514 & 78479 & 708 & 2392 & 51 \\
\hline Kalimantan Tengah & 30347 & 305 & 21950 & 160 & 584 & 11 \\
\hline Kalimantan Selatan & 40029 & 299 & 35531 & 103 & 1141 & 6 \\
\hline Kalimantan Utara & 16286 & 284 & 13123 & 172 & 243 & 3 \\
\hline Sepulauan Riau & 36581 & 928 & 27657 & 347 & 826 & 31 \\
\hline NTB & 16331 & 333 & 13337 & 210 & 533 & 2 \\
\hline Sumatera Selatan & 36945 & 556 & 29430 & 300 & 1707 & 15 \\
\hline Sumatera Barat & 61350 & 641 & 51508 & 316 & 1347 & 0 \\
\hline Sulawesi Utara & 19720 & 306 & 15957 & 89 & 607 & 6 \\
\hline Sumatera Utara & 44535 & 814 & 35379 & 217 & 1319 & 14 \\
\hline Sulawesi Tenggara & 13817 & 159 & 11336 & 126 & 284 & 6 \\
\hline Sulawesi Selatan & 72239 & 434 & 64778 & 349 & 1094 & 17 \\
\hline Sulawesi Tengah & 16792 & 251 & 13677 & 72 & 473 & 7 \\
\hline Lampung & 28009 & 677 & 20791 & 176 & 1253 & 11 \\
\hline Riau & 82107 & 847 & 72081 & 639 & 2190 & 28 \\
\hline Maluku Utara & 8204 & 84 & 5270 & 90 & 179 & 6 \\
\hline Maluku & 12127 & 69 & 7913 & 23 & 187 & 0 \\
\hline Papua Barat & 15902 & 156 & 11626 & 147 & 235 & 3 \\
\hline Papua & 23385 & 135 & 11846 & 67 & 216 & 3 \\
\hline Sulawesi Barat & 6919 & 90 & 5841 & 30 & 137 & 1 \\
\hline NTT & 28363 & 565 & 18276 & 141 & 537 & 2 \\
\hline Gorontale & 6790 & 102 & 5817 & 31 & 197 & 0 \\
\hline & & & & & & \\
\hline
\end{tabular}

B. Implemtasi Pada Tool Weka

1. Pertama - tama Explore Dataset kedalam tool Weka dalam format csv atau xls

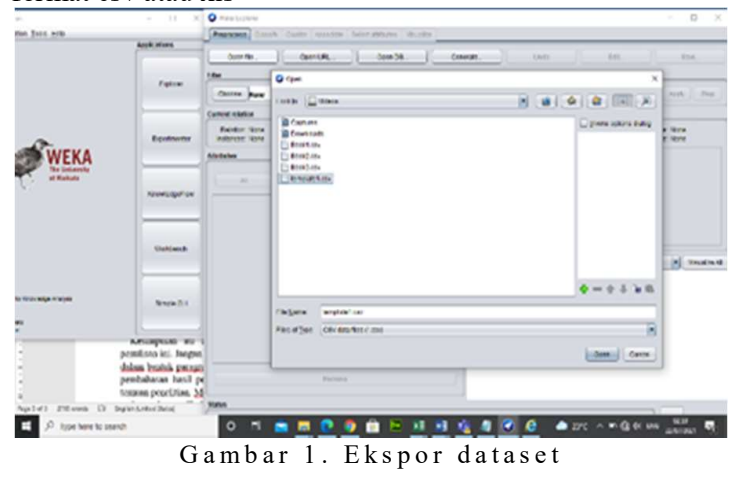

2. Pilih Algoritma cluster kemudian tentukan metodenya yaitu SimpleKmeans

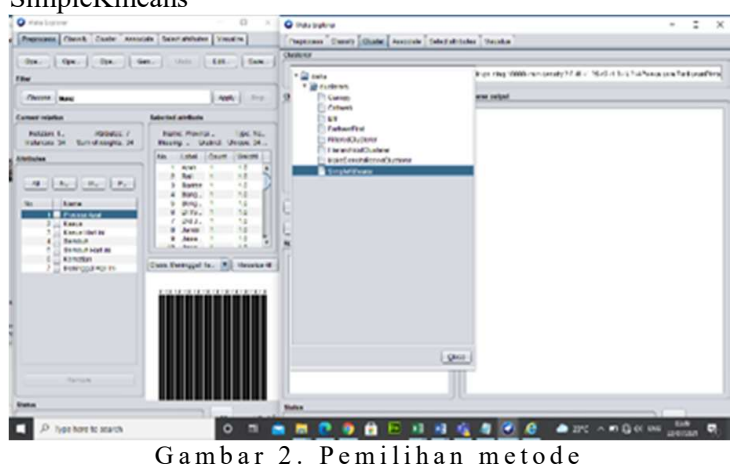

3. Selanjutnya kita masukan jumlah cluster yang sudah kita tentukan sebelumnya dengan cara double klik pada simpleKMean

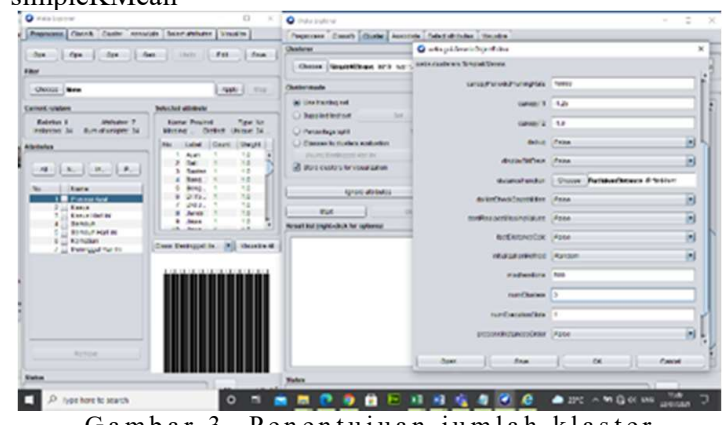

Gambar 3. Penentujuan jumlah klaster

4. Akan diperoleh hasil seperti berikut ini

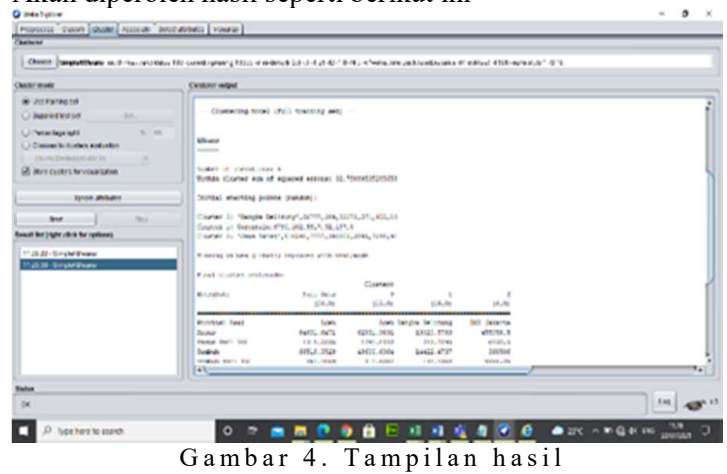


C. Hasil

Dengan Menggunakan Tool Weka hasil dari Perhitungannya Secara otomatis langsung di proses oleh komputer tanpa harus menghitung secara manual lagi, berikut ini adalah hasil dari perhitungan metode Kmeans.

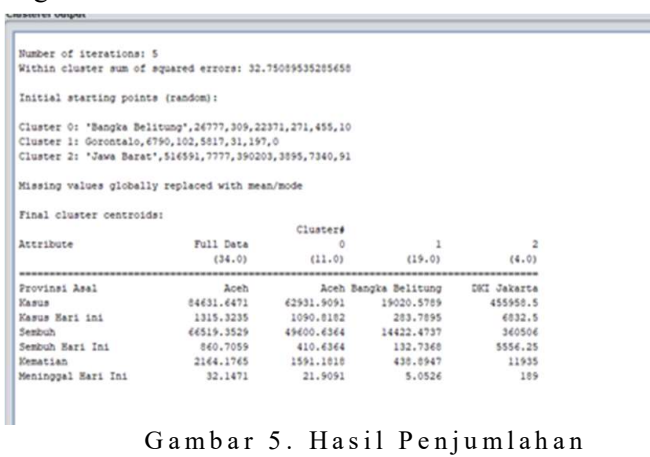

1. Initial starting poin (Random) merupakan titik awal centroids yang di mana apa bila kita menghitung dengan cara manual kita menetukannya sendiri secara acak karena kita mengunakan tool weka maka secara otomatis akan terpilih dengan sendirinya

2. Final Cluster Centroids adalah hitungan pusat rata rata Cluster dengan keanggotaan Cluster yang sekarang

Terdapat 3 pembagian hasil Clustering dengan rincian Cluster 0 terdiri dari 11 hasil data, cluster 1 terdiri dari 19 hasil data, cluster 2 terdiri dari 4 hasil data.

D. Pengelompokan Zona

Zona di kelompokan berdasarkan hasil pembagian dari perhitungan clustering. Terdapat 3 cluster untuk menetukan status zona yang telah ditentukan dan di peroleh hasil cluster 0 , cluster 1 dan cluster 2. Berdasarkan hasil yang kita peroleh melalui perhitungan dengan batuan tool weka. Cluster 2 dikategorikan sebagai zona merah karena cluster tersebut termasuk status zona penyebaran covid 19 tingkat tinggi, cluster 0 bewarna orane melambangkan bawah cluster tersebut termasuk ke status zona penyebaran covid-19 tingkat sedang dan cluster 1 bewarna kuning melambangkan penyebaran covid tingkat rendah

Tabel 2. Pengelompokan Zona Berdasarkan Hasil Pembagian dari Perhitungan Clustering

\begin{tabular}{|c|l|}
\hline Provinsi Asal & Cluster \\
\hline Aceh & cluster0 \\
\hline Bali & cluster0 \\
\hline Banten & cluster0 \\
\hline 'Bangka Belitung' & cluster1 \\
\hline Bengkulu & cluster1 \\
\hline 'DI Yogyakarta' & cluster0 \\
\hline DKI Jakarta' & cluster2 \\
\hline Jambi & cluster1 \\
\hline 'Jawa Barat' & cluster2 \\
\hline 'Jawa Tengah' & cluster2 \\
\hline 'Jawa Timur' & cluster2 \\
\hline
\end{tabular}

\begin{tabular}{|c|c|}
\hline 'Kalimantan Barat' & cluster1 \\
\hline 'Kalimantan Timur' & cluster0 \\
\hline 'Kalimantan Tengah' & cluster1 \\
\hline 'Kalimantan Selatan' & cluster1 \\
\hline 'Kalimantan Utara' & cluster1 \\
\hline 'Kepulauan Riau' & cluster0 \\
\hline 'Nusa Tenggara Barat' & cluster1 \\
\hline 'Sumatera Selatan' & cluster0 \\
\hline 'Sumatera Barat' & cluster0 \\
\hline 'Sulawesi Utara' & cluster1 \\
\hline 'Sumatera Utara' & cluster0 \\
\hline 'Sulawesi Tenggara' & cluster1 \\
\hline 'Sulawesi Selatan' & cluster0 \\
\hline 'Sulawesi Tengah' & cluster1 \\
\hline Lampung & cluster1 \\
\hline Riau & cluster0 \\
\hline 'Maluku Utara' & cluster1 \\
\hline Maluku & cluster1 \\
\hline 'Papua Barat' & cluster1 \\
\hline Papua & cluster1 \\
\hline 'Sulawesi Barat' & cluster1 \\
\hline 'Nusa Tenggara Timur' & cluster1 \\
\hline Gorontalo & cluster1 \\
\hline
\end{tabular}

\section{KESIMPULAN DAN SARAN}

Berdasarkan penelitian yang sudah kita lakukan di atas maka dapat ditarik kesimpulan bahwasanya algoritma clustering KMeans dapat di terapkan dalam pengeolaaan kasus data covid-19 dalam menentukan Tingakatan Status zona penyebaran covid 19 di provinsi indonesia, dengan batuan tool weka maka proses perhitungannya lebih mudah dalam membatu mendapatkan hasil di penelitian ini. Terdapat 4 provinsi yang termasuk ke zona merah, 11 provinsi zona orange dan 19 provisi zona kuning.

Tentunya dalam penelitian ini masih banyak kekurangan sehingga penelitian ini masih perlu dikaji sehingga dapat di kembangkan dalam membatu penanganan kasus data covid-19.

\section{DAFTAR PUSTAKA}

[1] N. Dwitri, J. A. Tampubolon, S. Prayoga, P.P.P.A.N.W. F Ilmi R.H Zer, D Hartama (2020) "Penerapan Algoritma KMeans Dalam Menentukan Tingkat Penyebaran Pandemi Covid-19 Di Indonesia,"

[2] E. Bu'ulolo, B. Purba (2021) "Algoritma Clustering Untuk Membentuk Cluster Zona Penyebaran Covid-19”Digital Zone : Jurnal Teknologi Informasi \& Komunikasi

[3] A. H. Ardiansyah, W. Nugroho, N. H. Alfiyah, R. A. Handoko, M. A. Bakhtiar (2020) "Penerapan Data Mining Menggunakan Metode Clustering Untuk Menentukan Status Provinsi Di Indonesia 2020" Seminar Nasional Inovasi Teknologi.

[4] S. Pujiono, A. Amborowati, M. Suyanto (2013) “Analisis Kepuasan Publik Menggunakan Weka Dalam Mewujudkan Good Governance Di Kota Yogyakarta” Jurnal Dasi 